\title{
Russell West-Pavlov Trumpets and Strumpets: Time, Space, Emulation and Violence in Shakespeare's Troilus and Cressida
}

Abstract: In this article I examine a number of scenes in Shakespeare's Troilus and Cressida where trumpet calls punctuate the action, arguing that they index forms of early modern masculine warrior identity. The apparently peripheral theatrical signs highlight, by means of their acoustic semiosis, forms of masculinity imbricated in processes of self-perpetuating violence. That spiralling violence is referred to at one juncture, as a 'rank feud' (4.7.16) - a conflict both growing out of control but also one centred around 'rank', that is, hierarchical competition generating violence out of violence. I claim that the play, by exploring the deeply oxymoronic structure of the masculine warrior ethos, what it in the context of Hector and Ajax' duel calls, 'A gory emulation 'twixt us twain' (4.7.7), points to broader structures of endemic conflict in early modern English society. The play repeatedly uses the term of imitative 'emulation' to index this phenomenon. Such a term, though referring specifically to internecine aristocratic competition, in turn pointed to wider patterns of violence which were of great concern to contemporaries, but which changes in English society down the seventeenth century would gradually make obsolete. The theatre, I suggest, unwittingly imagined these transformations by its very aesthetic form, '[a]nticipating time' in Agamemnon's phrasing (4.6.2). It did so not out of any uncanny prescience, but because the early modern theatre's own variety of imitative 'emulation', albeit short-lived, was one sector of an emergent capitalist economy in whose interests social strife, culminating in the civil wars and the collective trauma of 1649 , would be increasingly curtailed as the century entered its last quarter.

Russell West-Pavlov, Universität Tübingen and University of Pretoria E-Mail: russell.west-pavlov@uni-tuebingen.de

In one of the crucial scenes of Shakespeare's Troilus and Cressida (1602-1603; all references to Shakespeare 1988), a Greek "trumpet sounds" calling the Trojan Hector to an engagement with the Greek Ajax (4.6.11) in a single combat which is supposed to rouse the reluctant hero Achilles to a renewed warlike vigour. Ulysses remarks "No trumpet answers", to which Achilles replies "'Tis but early 
days" (4.6.12-13). After all, the Greeks have arrived early, "[a]nticipating time”, as Agamemnon observes (4.6.2). But the absence of a responding trumpet call is significant, marking as it does an anomalous temporal structure and an ambiguous spatial complex, both of which are central to the play's message.

The trumpet is no mere naturalistic adornment. It is a complex acoustic (or paralinguistic) theatrical sign (see for instance Pfister 1988, 8; Turner 2006, 159), one that does considerable work in the semiotic structure of the drama: it signals a general scenario, that of war; it marks a place, that of the camp (whether here or there, friend or foe, on-stage or off-stage); it marks a time, that of the threshold to combat (or sometimes the reverse threshold, that of its cessation, as in a retreat). The answering trumpets thus mark out two camps, connected via their enmity, and two moments: attack and repulse, the two temporal segments of a single battle. Trumpets were part of the large panoply of auditory effects which supplemented the human voice in the early modern theatre, in this case an iconic actor-body sign (Smith 1999, 217-220; Turner 2006, 159). They were important enough in the dramatic apparatus to figure in Henslowe's list of props for the Admiral's Men in 1598: “[I]ij trumpettes and a drum” (Foakes 2002, 318). Jonson's Morose, in The Silent Woman, dreads the thought of having to "sit out a play, that were nothing but fights at sea, drum, trumpet, and target!" (Jonson 1925-61, 5.230) - Morose's "nothing but" hyperbolically emphasizes the importance of such signs within the theatrical semiotic economy. Even later commentators seemed to appreciate such dramatic elements, or at least their significance if not their effects, with Dryden bemoaning in his 1697 preface to the play its final "confusion of drums, trumpets, excursions and alarms" (qtd. in Martin 1976, 31).

The semiotic work done by such musical instruments was considerable. In this specific case, the heavily underlined absence of an answering trumpet call is crucial for the semiotic process of Troilus and Cressida, for a number of reasons. First, the failure to gain a response signifies a momentary disruption in a significant temporal structure, that of a war which has been going on for seven years (1.3.12) and whose potentially endless perpetuation is heavily debated by the warriors on both sides. The trumpet call awaiting a response here announces the duel between Hector and Ajax, a duel intended to fill a hiatus in the hostilities and kick-start warrior sensibilities getting slack for lack of practice. The momentary pause opened up by the non-answering trumpet call is analogous to another temporal hiatus in the war, a brief friendly meeting between the warriors, an "extant moment [of] faith and troth,/strained purely from all hollow bias-drawing" jammed between "what's past and what's to come ... strewed with husks/and formless ruin of oblivion" (4.7.50-53).

Second, however, these moments of waiting or of amicable communion are not truly anomalous, for they reveal, by contrast, the underlying temporal mo- 
tor of the war. That driving force is a masculine ethos of warlike bravour which depends upon ongoing conflict to reinforce its warrior identity, epitomized in Troilus's closing vow of revenge: "No space of earth shall sunder our two hates./I'll haunt thee like a wicked conscience still” (5.10.27-28).

Third, these temporal aspects point, finally, to a psycho-spatial complex already indexed in Troilus's "No space of earth shall sunder our two hates", and ostended acoustically in the responding trumpet calls: namely, a form of enmity which conceals masculine comradeship even (and especially) among ostensible enemies unto death. This comradeship is attached by strong but paradoxical affects to its putative enemies, objects of the "noblest hateful love, that e'er I heard of", in Paris's wry oxymoron (4.1.34).

In this article I argue that both time and place, together constructing forms of early modern masculine identity, are pointed up by these apparently peripheral theatrical signs, in the acoustic semiosis of trumpet calls. I suggest that what is highlighted, by virtue of its temporary suspension, is a long-running process of self-perpetuating violence. That spiralling violence is referred to, in Hector and Ajax' microcosmic duel, as a "rank feud" (4.7.16) - a feud both growing out of control but also one centred around 'rank', that is, hierarchical competition generating violence out of violence. I claim that the play, by exploring the deeply oxymoronic structure of the masculine warrior ethos, what the play calls in the context of Hector and Ajax' duel, “A gory emulation 'twixt us twain” (4.7.7), points to broader structures of endemic conflict in early modern English society. The play repeatedly uses the term of imitative 'emulation' to index this phenomenon. Such a term, though referring specifically to internecine aristocratic competition, in turn pointed to wider patterns of violence which were of great concern to contemporaries, but which changes in English society down the seventeenth century would make gradually obsolete. The theatre, I suggest, unwittingly imagined these transformations by its very aesthetic form, "[a]nticipating time" in Agamemnon's phrasing (4.6.2). It did so not out of any uncanny prescience, but because the early modern theatre's own variety of imitative 'emulation', albeit short-lived, was one sector of an emergent capitalist economy in whose interests social strife, culminating in the civil wars and the collective trauma of 1649 , would be increasingly curtailed as the century entered its last quarter.

In what follows, I focus on a number of scenes in Troilus and Cressida where trumpet calls punctuate or re-direct the dramatic action. I suggest that, at each of these acoustically marked junctures in the play, Shakespeare's usage of auditive signs register the age's concern with violence while simultaneously signalling their own theatricality. It is this self-reflexive turn which, by addressing the problem of imitation, may offer an implicit resolution to a structure its action portrays as hopelessly self-perpetuating. 


\section{Trumpets ...}

As is well known, the early modern theatre used little in the way of set equipment to concretize in the theatrical here-and-now its fictional (dramatic) settings. Instead, its mode of "dramatic deixis" (Elam 1980, 72-74, 113) depended upon verbal and aural marking of time and place (Angerer 1965; Styan 1996, 145-147). This made for a remarkable fluidity of switches of time and place, and generated a theatre, which despite the length of its plays, was marked by notable speed of action (Dietrich 1965, 195) - and "Troilus and Cressida ... is unique even among Shakespeare's works for its changes of viewpoint from scene to scene" (Muir 1982, 20). This fluidity is exemplified in the play in successive scenes following shortly upon the episode treated above, where two almost simultaneous trumpet calls are heard $(4.5 .139,4.6 .11)$. They mark two temporally contiguous moments, and two contiguous spaces, those of the Greek and Trojan camps respectively.

The first trumpet call is marked as a stage direction, as well as being verbally ostended: “Hark, Hector's trumpet!” (4.5.140) exclaims Paris. The trumpet call thus functions as an auditive punctuation in the action: Troilus, Cressida and Diomedes leave the stage for Cressida to be handed over to the Greeks; those left on the stage, Paris, Aeneas and Deiphobus, have been party to the imminent exchange, but are now recalled to their warrior duty by their general's trumpet. Following this immediately, there is a change of 'scene': that is, the Trojans leave the stage, and the Greeks enter, thus signalling via actor-indexed deictic re-orientation (Elam 1980, 145; cf. West 2002, 57) that we are now on the other side of the 'frontline'. At this moment, a second trumpet call is heard. Agamemnon says to Ajax:

Give with thy trumpet a loud note to Troy, Thou dreadful Ajax, that the appallèd air May pierce the head of the great combatant And hale him hither. (4.6.3-6)

Ajax turns to his trumpeter and orders him:

Thou trumpet, there's my purse.

He gives him money

Now crack thy lungs and split thy brazen pipe.

Blow, villain, till thy spherèd bias cheek

Outswell the colic of puffed Aquilon.

Come, stretch thy chest and let thy eyes spout blood;

Thou blow'st for Hector.

[The trumpet sounds]. (4.6.6-11) 
The two trumpet calls respectively emanate from and are directed at Hector. They reply to one another both temporally and spatially, with little interval between. This contiguity which is almost identity is underlined by the marking of a change of fictional-world space only by a change of actors, ostended by the verbal explanation of the trumpet calls. In a theatre system where transitions in the action were "closely linked to character groupings and their movements" and where often "these movements are not correlated with any sense of "place" " and "the relation between onstage and offstage remains as elusive as ever" (Turner 2006, 182) the trumpet calls has a crucial role in marking out the minimal and blurred distinctions of premodern war. The real stage space is the same, and its marking is only differentiated by a trumpet call offstage and then onstage.

In fictional dramatic terms, the respective Greek and Trojan spaces are different but adjacent to one another. In real space-time theatrical terms, however, they are the same, marked only by a change of military personnel. The audience registers both regimes of semiotic marking, in a sort of 'double vision' that is characteristic of all theatrical semiosis (cf. Barthes 1975, 106-107). Rather than the 'distal' or 'proximal' deictic markers of 'here' and 'there' (Levinson 1983, 62), it would be perhaps more accurate to speak of a "t/here" constructed within the real space-time domain of the stage. What this blurring of putatively opposed spaces suggests, in concrete spatial terms, is the near-identity of the opposed Greek and Trojan parties, which Shakespeare's drama emphasizes by its erosion of the apparent 'modern/Machiavellian' vs. 'traditional/chivalrous' valencies accorded to the Greeks and Trojans respectively: even Troilus condemns the "Fools on both sides" (1.1.90) (see also Cole 1980; Greenfield 2000).

Let us turn to another trumpet call (suspended in this case) which underlines the way putative aggression conceals a deeper and more insidious identity of values and ideals among the warring parties. Towards the end of the play, Hector orders, "Ho! Bid my trumpet sound"; his sister Cassandra, giving support to the warrior's distressed wife Andromache, who has had premonitions of his imminent death, enjoins him, "No notes of sally, for the heavens, sweet brother" (5.3.13-14). Here the trumpet call, narrated rather than performed, is to give the order to "sally" forth. It is a vectorial marker pointing up the tension between the 'proximal' and 'distal' deictics 'here' and 'there'. This trumpet call links the others, located as they are within the mutually interchangeable 'heres' and 'theres' of the Greek and Trojan camps respectively. Its linking role is expressed clearly by Hector when he explains, "I do stand engaged to many Greeks,/Even in the faith of valour, to appear/This morning to them" (5.3.7072). Hector is "engaged" by the "faith of valour", a currency of warlike exchange, a "noblest hateful love" (4.1.34) which makes soldiers kin with one another over above more intimate bonds (cf. Pietzcker 2001). It is notable, how- 
ever, that the verbally anticipated trumpet call is not executed. Feminine agency, bucking the yoke of patriarchy, temporarily disturbs the kinship of warriors and its concomitant economy of spiralling violence, but cannot forestall it altogether: soon an "alarum", and "Exit Priam and Hector severally" marks the resumption of hostilities (5.3.97, s.d.).

Shakespeare dramatizes such violence-ridden homosociality when he has the Trojan warrior Aeneas, meeting his Greek counterpart Diomedes in a moment of truce, announce, "By Venus' hand I swear,/No man alive can love in such a sort/The thing he means to kill more excellently" (4.1.23-25). Diomedes replies using the term of "emulous honour" (4.1.29), the competitive imitation which translates into violence, generates conflict but is sustained and nourished by that selfsame conflict. Similarly, Achilles's summary of Hector's elaboratelystaged disdain for his duelling partner Ajax, "A little proudly, and great deal disprising/The knight opposed" (4.6.76-77) deploys a striking double negative which adds up to a positive. Yet, rather than evincing an impetus towards social stability, such anecdotes give disturbing evidence of self-generating violence as an integral dynamic within the body politic.

Early modern England, like much of early modern Europe (Roper 1994, 112) was characterized by endemic violence. In the generalized fear of invasion, the entirety of English society was equipped for conflict: early seventeenth-century legislation stipulated that every householder, "who soever he is", must have "in a readiness, such armes as is appointed by the Commisioners ... at least a bill, sword, or dagger" (Thomas Wilson, The State of England, Anno Dom. 1600, qtd. in Mallin 1990, 145). Individual instances of violence are frequent. One anecdote from 1637 tells of two friends named Thomas Pouncey and Richard Paty drinking together in a Dorchester alehouse. They quarrelled over some matter, whereupon they went outside and fought it out with their fists. "All bloody with fighting", they then went back inside and resumed their companionable drink. Further up the social scale, the nineteen-year-old Earl of Essex picked a quarrel with Sir Charles Blount (later Lord Mountjoy) and was reprimanded by Queen Elizabeth; the two men later became good friends (Underdown 1993, 164; Kiernan 1988, 80). The rapidity of reconciliation does not mitigate such conflict, but, on the contrary, shows how much it was part of social bonding, and therefore difficult to eradicate. Such counterpoised social energies could not but create insurmountable frictions. At the larger level of the global Troy plot, Priam lists as the costs of violent conflict the "damage" to "honour, loss of time, travail, expense,/Wounds, friends, and what else dear that is consumed/In hot digestion of this cormorant war" (2.2.3-6).

But some differentiation is necessary here. The widespread concern about aristocratic and gentry violence manifested in duelling may reveal not only an 
ongoing prevalence of social conflict, but also a significant shift in its location. In general, military prowess as a marker of aristocratic prestige underwent a decline in the course of the seventeenth century. Notwithstanding perennial laments that the "historical moment" of manly warrior aristocracy "has already passed" (Katherine Eisaman Maus, qtd in Johnston 2008, 13), English society did evince a gradual transition to the hegemony of an emergent bourgeois civic masculinity (see for instance Barker-Benfield 1992, in particular ch. 2; King 1999). The Civil Wars provided a last brief opportunity for the display of military bravery, but by the end of the century, the aristocratic warrior identity had become largely obsolete. Armies were becoming increasingly professional (Clarke 1934, 102-114), and the nexus aristocracy-military honour was being diverted into the cul-de-sac of rake profligacy. "In the later seventeenth century, the nobility and gentry became overwhelmingly civilian in style and appearance. ... [M]ilitary reputation dwindled in importance as a component of aristocratic honour" (Thomas 2009, 60-63, 64).

By contrast, another form of violence, duelling, may have grown in significance as the loci of masculine violence shifted in the course of the seventeenth century from warfare to the personalized domain of single feuds (Barber 1957, 263-272). James I passed several edicts against duelling, albeit with limited effect (Willson 1966, 305ff.). Plays such as A Fair Quarrel (1615-1617) dealt with the issue of duelling, registering James's attempts to stamp out such ritualized practices of violence among the gentry (Heinemann 1980, 114-115). Duelling as a perceived problem clearly fluctuated, dwindling early in the century, then experiencing renewed acceptability under Charles II, but going into decline again under the Hanoverians (Sharpe 1987, 170-210); Fynes Morrison in his 1607 Itinerary could speak of it as a phenomenon of the past, mentioning as causes of the decline of such forms of hypermasculine violence "the dangerous fight at single rapier, and the confiscation of man-slayer's goods” by judges (qtd. in Wilson 1959, 129). This may not have been an entirely accurate reflection of actual trends, but it certainly indexes a critique of duelling as a domesticated and individualized metastasis of warfare.

Shakespeare's Troilus and Cressida, especially in its oblique attack on the discredited Earl of Essex (Wells 2000, 34-60), or its allusion to incompetent and futile campaigns in the Low Countries, among others the siege of Ostend from 1601-4 (De Somogyi 1998, 238ff.), can be seen as an early index of this gradual shift in paradigmatic versions of masculinity from the warrior-aristocratic towards the civic-bourgeois; but by the same token, the unevenness of this transition is indicated by the play's orchestration of various duel-like oneon-one combats (Hector-Ajax) and personal feuds (Troilus-Diomedes), thus indexing residual forms of individualized violence. 
If the play appears to be located, in historical terms, on the long cusp between the demise of warfare as the realm of aristocratic honour and its residual but dwindling 'afterlife' in duelling (cf. Barber 1957, 12-14), such ambivalence is evident in Troilus and Cressida at every level. In conceptual terms, the play seems to be torn between two contrasting ethos: "[I]n Troilus and Cressida a gap is opened up between the civilized understanding of these issues possessed by both sides" - for instance, "Hector showing his acquaintance with the moral laws of nature and of nations, defined by Hooker in The Laws of Ecclesiastical Polity" - and "a barbaric addiction to fighting that defies reason and common sense” (Foakes 2003, 170-171). In Shakespeare's drama, warfare and the warrior masculinity it depends upon are discredited. However, the underlying mechanisms of aggressive, imitative competition driving those forms of masculinity were clearly still effective, though displaced in to other social loci such as duelling. The play, to the extent that it indexes such metastases of violence by dramatizing individual combats and feuds, registers Shakespeare's critique of ongoing forms of self-perpetuating violence.

What Shakespeare's drama scrutinizes particularly acerbically, however, is not merely the prevalence of violence, but its affective charge, its tendency to become a constitutive element of "homosociality" (Sedgwick 1985) so that it functions as a self-perpetuating structure. 'Emulation', the desire to become like that which one aggressively seeks to displace, an impulse at once both imitative and hostile, was the name given to this oxymoronic form of homosociality.

Ulysses's famous speech on degree diagnoses "an envious fever/Of pale and bloodless emulation", a form of insubordination in which envy drives inferiors to aspire to the place of their superiors (1.3.133-134). Here emulation is imagined as a disintegrative, centrifugal force. This presentation was related to the ambiguity of the term inherent in the early modern philosophical notion of 'aemulatio', one of the forms of resemblance central to the representational systems of early modern European thought. 'Aemulatio' referred to the similarities between entities situated in different sectors of the universe. Yet 'aemulatio' also had the potential to upset hierarchies by virtue of the 'joust', 'tournament' or 'duel' that might ensue as the one or the other entity exerted an influence beyond its place (Foucault 1966, 34-36; 2002, 21-23, translation modified). In contrast, Shakespeare's drama takes a more complex stance. Troilus and Cressida detects in 'emulation' an imitative, indeed mimetic and collective structure (see Girard 1985), not only in its narcissistic functioning ("pride hath no other glass/To show itself but pride”, 3.3.47-48) but in its tendency to replicate the violence by which it seeks to annihilate and thus usurp the place of that with which it identifies ("Disprais[ing] the thing that you desire to buy", 4.1.88). It is emulation's centripetal, self-consolidating dynamic and emphatically not the 
'neglection of degree' (1.3.127) that generates centrifugal effects, provoking a spiral of violence depicted in large format in the narrative of Troy itself. Emulation, in Shakespeare's vision, is not anomalous within the social order, but rather, constitutes the central social energy within warlike aristocratic society. Significantly, Ulysses, in attacking emulation, embodies that which he decries, for his speech is an oblique critique of Agamemnon's leadership. In the very moment Ulysses arraigns 'emulation', he performs and perpetuates it.

\section{Emulation}

Not only is Ulysses's speech an instance of performative contradiction which intensifies the problem it diagnoses; it further obscures the nature of the problem by projecting social differences onto a vertical scale of hierarchy. The core issue, in Ulysses's account, is insurbordination against natural rank. In fact, however, there was little difference in degree, or even in appearance, between those who competed via imitation for the same aristocratic laurels: "Because court factionalism was an equilibrating structure, it spurred the nobles to augment the distinctions that it dissolved. ... In a system that promoted nullifying balance, that calibrated power relations to the disadvantage of those most actively engaged in it, every self-creative gesture produced only imitation" (Mallin 1990, 151). An "emulous" (2.3.228) identity had to differentiate itself via imitation (i.e. doing the same thing better) against a background of identification with similar others, thus generating what Nestor calls "[c]o-rivalled greatness" (1.3.43). Because similarity between equals was so great, the need for differentiation produced exaggerated effects. This impulse to imitation in the service of differentiation was expressed hyperbolically in its chiastic twin, differentiation in imitation, i.e. violence against one's identical peers, because they were mirrors of oneself, having "no other glass/To show itself" (3.3.47-48) (cf. Charnes 1989, 433)

The metaphor which constantly recurs to give expression to this internecine strife is that of self-consumption. Ulysses describes insurbordination as "an universal wolf" which "So doubly seconded with will and power,/Must make perforce an universal prey,/And last eat up himself” (1.3.121-124). Likewise, Agamemnon intones, "He that is proud eats up himself" (2.3.153). But it is emulation between equals because of their equality, not of superiors by minions, which devours itself: Thersites describes Diomedes and Troilus and their personalized feud, in which Cressida links them in an unholy alliance, in such terms: "What's become of the wenching rogues? I think they have swallowed 
one another. I would laugh at that miracle - yet in a sort lechery eats itself" (5.4.30-33). These characters can be, properly speaking, described as 'neurotic' within the framing ideology that drives them, embodying "a politics of rebellion turned back upon the self” (Charnes 1989, 415), thus developing self-annihilating tendencies.

Yet this self-devouring structure, although it expresses the damage to the body politic contemporary commentators feared, seems incapable of exhausting itself: "For emulation hath a thousand sons/That one by one pursue", says Ulysses ominously to Achilles (3.3.150-151). Rather, 'emulation' generates a selfperpetuating dynamic epitomized in the apparently endless siege of Troy. The question Aeneas asks before Hector and Ajax's duel, "Will you the knights/Shall to the edge of all extremity/Pursue each other' (4.6.69-71), may be the central question the play asked its early modern spectators. If Agamemnon rather too optimistically foresees, at the end of 5.10, the imminent close of the war, only a moment later, Troilus is vowing eternal revenge upon Achilles for the death of his brother Hector: "[T]hou great-sized coward,/No space of earth shall sunder our two hates./I'll haunt thee like a wicked conscience still” (5.10.26-28).

However, this masculinity predicated upon self-perpetuating violence does not go entirely unquestioned in the play. Replying wittily to one instance of many epicurean topoi of manliness, Pandarus's typology of the heroic virtues which constitute "the spice and salt that season a man", Cressida quips that "the man's date is out” (1.2.251-253). Cressida's pun is one index of the way Shakespeare's play struggles to articulate two contradictory notions: the sense of a temporality of endlessly spiralling violence, and a counterpoised conviction that such structural violence could not continue indefinitely but must somehow bring about its own demise. As Keith Thomas writes,

military prowess ... was the oldest and most basic form of masculine self-realization, and it was still highly admired within the specific context of professional soldiering. But, as a universal aspiration, it had had its day. It was too closely associated with a rudimentary economy and an archaic social structure; it was exclusively masculine; and its moral value was highly contested. (Thomas 2009, 76)

It would cede to "other, more peaceful ways in which men and women, at all social levels, sought to fulfil themselves" (Thomas 2009, 76). In what follows, I will suggest that it is on the terrain of exchange, that entrepreneurial vernacular peculiar to the theatre and its own 'emulative' exchange of identities, that this paradigm shift to come is rehearsed, "[a]nticipating time" (4.6.2), in Shakespeare's drama. Yet that paradigm shift can only be gestured at in contrast to a residual feudal economy which Troilus and Cressida places in an extremely critical light. 


\section{... and Strumpets}

The review of trumpet calls in Troilus and Cressida which has punctuated my argument so far would not be complete without a further "flourish" (4.6.64, s.d.), which is immediately commented upon by the Greeks, 'The Trojans' trumpet'. This trumpet call is followed by the entry of the Trojans ("Enter all of Troy"), and Agamemnon's redundant commentary, "Yonder comes the troop" (6.4.66). These indexical statements announce the imminent duel between Hector and Ajax. Famously, however, this verbal ostentation has also been read homonymically as 'The Trojan strumpet'. Heard in this way, it forms a concluding commentary upon the kissing scene between Cressida, newly delivered up, and the Greek warriors. (That this homonym is no accident is indicated by the virtually identical verbal ostentation of another trumpet call at 5.9.15, "The Trojan trumpets" [5.9.16], where no ambiguity is possible).

This trumpet call, highlighted by its homonymic verbal echo, thus is a bifurcated temporal marker. It points forward to the resumption of hostilities, but at the same time, it gestures backwards, via the brief trading of Cressida among the Greek warrior males, to the other trumpet calls discussed above, together with which it forms a sort of framing clip.

In the light of these three trumpet calls, two of them marking the respective poles of masculine communication $(4.5 .139$, 4.6.11), with the third gesturing towards the exchange of women which underpins that homosocial communication, it becomes possible to re-envisage the monetary element which intrudes so oddly in Ajax's address to his trumpeter. Ajax says, "Thou trumpet, there's my purse”. He then "gives him money" (4.6.6, s.d.). Payment with a purse as a whole eschews exact calculation of value and thus eludes the financial calibrations of mercantile exchange. This form of non-calculation is in keeping with Troilus's refusal to buy into Hector's judicious assessment of Helen as "not worth what she doth cost/ The holding" (2.2.50-51), and his scoffing "Weigh you the worth and honour of a king/So great as our dread father in a scale/Of common ounces?" (2.2.25-27). Ajax' payment is only tenuously part of a mercantile exchange; rather, it indexes something which is much closer to the aristocratic tradition of conspicuous consumption (Fisher 1948), manifest in an ethos of noble largesse and hospitality, often ruinous to its practitioners (Turner 1979, 143), and conceptualized for 'premodern' societies by the notion of ostentatiously destructive potlatch (Bataille 1991). The remuneration is non-numeric, and the task demanded is similarly excessive in a corporeal sense: "Blow, villain, till thy spherèd bias cheek/Outswell the colic of puffed Aquilon:/Come, stretch thy chest and let thy eyes spout blood" (4.6.6-10). Such topoi gesture towards a warrior ethos of heroism measured in bloodshed, the ultimate manifestation of wasteful spending. 
Cressida's humiliating passing-around among the Greek warriors, where she manages to maintain a semblance of agency (see Tiffany 1993), only to be damned by Ulysses as a "daughter of the game" (4.6.64), marks the junction of a warrior ethic of affect-bonded bloodshed and another element of putatively 'premodern' societies: namely, the exchange of women as value-bearing entities (Irigaray 1985, 170-191) for the purposes of forging of alliances between otherwise hostile dynastic or clan groups (Lévi-Strauss 1968, 46-47). In the words of Saint Augustine (translated into English in 1610 and thus present to the minds of early modern people), marriage-exchange was instituted so "that them to whom concord was most vsefull, might be combined togither in diuerse bonds of kindred and affinity: ... and so many, by as many, should be conglutinate in honest congiugall society. ... As, father, and father-in-law, are two names of kindred" (Saint Augustine 1610, 552). This is the essence of 'homosociality', predicated as it is, in Sedgwick's formulation, upon "a desire to consolidate partnership with authoritative males in and through the bodies of females" (Sedgwick 1985, 36) - exemplified neatly in Augustine's account by the elision of the exchanged feminine subject in favour of the male brokers.

Cressida's exchange is isomorphic with the other exchange which provides the framing narrative of the play: the rapt of Helen. Helen is a pawn in the geopolitical machinations between the Greek and Trojan monarchs and generals; Cressida's exchange is arranged between males (Calchas, Agamemnon [3.3.17-33] and Priam [4.2.70]), and subordinates the wishes of the individualcum-token to the masculist interests of "the general state" (4.2.70). Even if the abduction of Helen is acknowledged as a "theft most base" (2.2.91), making it an exchange "manqué” and/or "faussé” (Todorov 1969, 78), and if Cressida's forced separation from Troilus is conceptualized as a metonymy of Helen's rapt, these exchanges of women none the less fulfil the same structural role: they become the mediating "interchange" (3.3.33) which facilitates masculine bonding, whether of a positive sort between families, or of a negative but no less affect-charged variety in combat. Indeed, Cressida's exchange may even be imagined as a reparatory exchange which remedies the theft of Helen. It may be understood as thus restoring the equilibrium in the exchange of women, and reestablishing marriage exchange in its central (patriarchal) structural-functionalist role (Gil 2001, 336).

The bonding function of exchange becomes most evident when Ulysses and Troilus together watch Cressida capitulating to the advances of Diomedes, with Thersites providing a cynical commentary in the background. Troilus and Ulysses, in fact enemies (Ulysses on two occasions names Troilus simply "Trojan" $[5.2 .30,127])$, are unified in their common gazing upon the beleaguered Cressida as she transfers her allegiance to Diomedes (5.2.6-114). The exchange 
has been orchestrated by the Greek Agamemnon and the Trojan Calchas with Priam adjudicating in Troy; now, as Diomede cashes in his dues for having escorted her between the two camps, the Greek Ulysses and the Trojan Troilus constitute secondary brokers of the exchange. They observe a sleazy bargain in which Cressida struggles in vain against the pre-ordained role of faithless wanton (see Fly 1975). They also witness Troilus's sleeve being passed over to Diomedes (5.2.96-97, 172-174), who in turn will wear it in battle as a challenge to the Trojan whose "luxurious drab" (5.4.8) he has acquired. In this way, the exchange of women, mediated by several groups of men unified by the exchange ("I'll bring you to the gate", offers Ulysses, to which Troilus replies, “Accept distracted thanks" [5.2.191]), becomes a sub-set of war, that other exchange between men. The verbal ostention of "The Trojan s/trumpet" (6.4.66) marks Cressida's transition from 'good' to 'bad' object of male exchange (i.e. from the dutiful object of exchange between father and father-in-law to the woman 'common' to many men).

Yet this exchange is performed, on stage, as a piece of theatre with an audience of three males, before another audience, the real paying audience of early modern London. ${ }^{1}$ Thus from within a nexus of aristocratic, masculist exchange mechanisms depicted on the stage, Shakespeare's theatre gestures towards other representational and commercial economies. Ulysses and Troilus are spectators whose meta-dramatic status signals the intervention of the theatre, circulating its own counter-currency of exchange, one predicated upon the "commercial potential” of the Troy material (Hillmann 1997, 295; cf. Bruster 1992, 3-4), into the interrelated processes of 'emulation', violence and exchange which it focusses and dramatizes.

\section{Theatre}

The theatre points constantly to its status as theatre - and does this also via the mechanism of acoustic signs. Let us attend to one final trumpet call: "A retreat sounded" (5.9.14, s.d.). Achilles observes, "Hark, a retreat upon our Grecian part”, to which, hearing "[Another retreat ... sounded]" (5.9.15, s.d.) the Myrmidons reply, "The Trojan trumpets sound the like, my lord" (5.9.16). Once again

1 I bracket here the considerable debates around the actual performance history of the play, which according to the (replacement) title-page of the play in the 1609 quarto was "a new play, never staled with the stage, never clapper-clawed with the palms of the vulgar" (Foakes 2006, 131; see also Chambers 1923, III, 487; Elton 2000). 
the Greek and Trojan trumpets echo each other, signalling the underlying affinity of the warriors ostensibly opposed in war. Yet this mutual echoing comes immediately after the Myrmidons' massacre of the defenceless Hector, for which Achilles immediately takes the credit (5.9.14). Here, the echoing trumpets point up the utter factitiousness of apparent chivalry. Achilles's warlike manliness is revealed to be a mere act, a façade which conceals its very opposite. Just as "[b] y playing Ajax and Achilles off against each other, Ulysses foments precisely that 'envious fever/Of pale and bloodless emulation' ... he had denounced as the upshot of 'neglection of degree'" (Ryan 2007, 176), so too it is Ulysses who, having attacked Achilles and Patroclus for their theatricalization of the Greek military elite, is revealed himself to be acting a part, instantiating the endemic duplicity of emergent merchant-capitalist society (Agnew 1986, 60). The double trumpet calls give the lie to Achilles' claims to heroism, and by the same token are themselves subject to ironic scepticism as the markers of warlike chivalry. They too are merely part of 'acted' martial chivalry hollowed out by a ubiquitous social theatricality.

Because of its metatheatrical resonances, this double fanfare thus anticipates the (possible) concluding trumpet peals which may sometimes have closed early modern plays: Thomas Dekker has a note "Ad Lectorem" at the beginning of Satiromastix to remind the reader of the auditive framing of the play, "the Trumpets sounding thrice, before the Play begin" (1953-63, I, 306). Smith notes, as the other half of such auditory 'framing', music at the close of some comedies, and a "tragic counterpart in the 'flourishes' of trumpets and/or the thudding of drums that are specifically called for the close 2 and 3 Henry VI, Macbeth, and The Two Noble Kinsmen" $(1999,262)$. No such closing trumpet is stipulated in the text of Troilus and Cressida, although the final "[Exeunt marching]" (5.11.31) may imply some sort of martial musical accompaniment. However, as it is not clear under what conditions the play was performed, one may at least speculate upon spectator experiences and expectations of such echoes between trumpet calls within the dramatic action and those which provided a framing function (Lotman 1977, 209-217). Be that as it may, the very fact of these instruments being transplanted into the theatre makes them not merely mimetic but 'emulative' signs, aware of their own metatheatricality - as well as of their echoes of carnivalesque usages in popular fundraising festivities such as in Wells, Somerset, where the "drummes fyfes and trompetts did sowne apace" loudly enough to come to the attention of the Star Chamber! (Smith 1999, 134). It can be plausibly claimed, then, that the drama snatched trumpets and similar martial instruments from the grasp of the militaristic aristocracy and made them, as in these examples, the metatheatrical hallmark of an 'emulative' but corrosive and upstart theatre which did not conceal its frank and unadorned will to profit. 
If the warrior aristocrat is thus laid bare as an actor in a social drama, as for instance Joseph Hall in his 1608 Characters of Vertues and Vices did in describing the 'emulative' social climber as being "euer on the stage, and acts still a glorious part abroad, when no man carries a baser heart, no man is more sordid and careless at home" (qtd. in Muir 1956, 243), then the theatre may be a crucial site of the demise of the warrior nobility, in which "acting like a man" is reduced to "acting like a man" (Spear 1993, 415). The corrosive parallels between war and theatre were manifold: war was understood as a theatrical spectacle; soldiers, notably, were like actors freed from the full force of sumptuary regulations (Thomas 2009, 60). Unlike soldiers, however, actors were not permitted to carry arms (Fernie 2007, 96) and could only 'emulate' the military. Marston, in Histrio-Mastix, confirms this: "[W]e players are privileged,/Tis our audience must fight in the field for us,/And we upon the stage for them" (qtd. in Mann 1991, 172). Troilus and Cressida implicitly pursues such parallels when it has the 'armed prologue' open the play by declaring, "Like or find fault; do as your pleasures are:/Now good or bad, 'tis but the chance of war” (Prologue 30-31).

Similary, but more subversively, Ulysses's speech on degree, which ironically describes and performs the self-destructive emulation it attacks, leads directly (at 1.3.146) into his description of Patroclus' and Axhilles' private theatre. Patroclus

with ridiculous and awkward action,

Which, slanderer, he imitation calls,

He pageants us. Sometime, great Agamemnon,

Thy topless deputation he puts on,

And, like a strutting player, whose conceit

Lies in his hamstring, and doth think it rich

To hear the wooden dialogue and sound

'Twixt his stretched footing and the scaffoldage,

Such to-be-pitied and o'er-wrested seeming

He acts thy greatness in. (1.3.149-158)

By virtue of the 'acting' of 'greatness' this theatre in the theatre bodies forth that 'emulative' imitation which Ulysses has just lambasted at such length. The scene includes a description of the audience:

At this fusty stuff

The large Achilles, on his pressed bed lolling,

From his deep chest laughs out a loud applause,

Cries 'Excellent! 'tis Agamemnon just.

Now play me Nestor .... (1.3.161-165)

Here are actors playing 'emulous' soldiers playing actors and audience. The theatre performs its own theatre in the theatre of war. In that way, it appropri- 
ates the destructive cycle of imitative, 'emulative' masculine competition and violence, and dovetails it with its own form of insubordination and 'emulation', so as to draw the Trojan War into its own sphere of influence. Critics such as Stein are right in suggesting that "In Troilus and Cressida the questions are pursued as if there are no answers. Something is fatally missing, and there is no one to know it, or to experience it for us or for the society which is falling apart" (Stein 1969, 166). However, the play does not merely submit the narratives of warlike chivalry to a scathing and nihilist critique by virtue of its reduction of heroes to bad actors. Rather, by having a pair of players as the main target of Ulysses's speech on degree, it suggests that its own form of 'emulation', the theatrical assumption of roles not available either to the players or most of the audience, within a new paying entertainment economy, may provide an alternative mode of exchange.

War is absorbed into theatre, thereby making it part of an economy of paying spectatorship: as Pandarus says early on to his niece, "Hark, they are coming from the field: shall we stand up here, and see them as they pass toward Ilium? ... Here, here, here's an excellent place; here we may see most bravely" (1.2.173-178). These self-reflexive references to acting inscribe the Trojan War narrative and its Shakespearean deconstruction within a new economy of entertainment as entrepreneurial exchange. This theatrical mode would be shortlived in its specific pre-1642-form to be sure, but capable none the less of "[a]nticipating time" (4.6.2) in its proleptic bodying-forth of a type of competition embedded in a capitalist economy for which war was inimical to optimal exchange (Jardine 1996, 37-90). In the course of the seventeenth century, in a process which Troilus and Cressida indexes in its own theatrical critique of the Troy narrative and its own theatrical intervention in that narrative, the meaning of 'emulation' itself would change. Out of 'emulation' as a masculist competition for aristocratic prestige, generating internecine violence, would evolve a relatively anodine, commodity-driven form of 'emulative consumption'. By 1678 Nicholas Barbon was praising emulative consumption for its role in the thriving London economy (Thomas 2009, 124-125, 138) - an economy in which Shakespeare's theatre had once dismantled the representational mechanisms of now residual aristocratic 'emulous factions' (2.3.72).

\section{Coda}

John Madden's immensely successful 1998 romantic comedy Shakespeare in Love stages a virtual love triangle between Will Shakespeare, Viola de Lesseps, 
and the older and more successful playwright Kit Marlowe. Marlowe, significantly, is "the first man among us", in Ned Alleyn's words (Norman and Stoppard 1999, 107), and "a crucial but vaguely defined presence in the film" (Anderegg 2003, 66). The love triangle is virtual because Kit Marlowe only becomes a member of the trio when Will, cornered by Viola's wrathful and vindictive suitor Wessex, is forced to identify himself. With Wessex' knife at his throat Will passes himself off as Marlowe, latter confirming this fiction anew (Norman and Stoppard 1999, 44-45, 92). Kit Marlowe thus becomes, by name only and without his knowing, the other lover of Viola de Lesseps, as he is pulled into Will's desperate web of lies; significantly, the tavern brawl Marlowe dies in is misunderstood, in neat Freudian slip, as being about "billing" (Norman and Stoppard 1999, 120). Here Viola figures as the vehicle/object of exchange of/between two men in something resembling a rapt narrative (Will has been described as a “thieving playwright” [Anderegg 2003, 56]), embellished with metatheatrical framing structures.

Upon the news of Marlowe's death in a tavern in Deptford, Will believes that he is indirectly responsible for Kit Marlowe's assassination at Wessex' bidding (Norman and Stoppard 1999, 111). Alleyn however explains to Will that Marlowe in fact died in a dispute about the bill. Relieved of the guilt of Marlowe's death, Will cries, “Oh God, I am free of it” (Norman and Stoppard 1999, 120). But Will is not merely freed of guilt; he is also freed of the oppressive burden of a Bloomian 'anxiety of influence' par excellence and can now go on to make his own place on the theatrical market. Will's hasty assumption of Kit Marlowe's name, albeit under duress, reveals his "upstart” (Norman and Stoppard 1999, 118) and 'emulative' desire to take the older playwright's place, literally, to be Kit Marlowe. This 'emulative' assumption of Marlowe's name betrays a substratum of aggression embedded in imitative admiration: Kit Marlowe appears to be indirectly and unintentionally deposed by his younger and as yet less accomplished emulator Will Shakespeare. "You never spoke so well of him", observes Viola upon hearing Will's eulogy of the deceased mentor; "He was not dead before", ripostes Will (Norman and Stoppard 1999, 111). In a fit of somewhat hypocritical grief, Will laments to Viola, "I would exchange all my plays to come for all of his that will never come” (Norman and Stoppard 1999, 111). There is indeed an exchange, but it is a brutal one, for by changing places with Kit Marlowe, Will effectively usurps all of Marlowe's unwritten masterpieces with those that he himself will now pen. In the film's imaginary history, according to Greenblatt, Marlowe's “death serve[s] as the turning point of Shakespeare's career" (qtd. in Menon 2008, 115). Shakespeare will rise to prominence in the place of Marlowe, his theatre, "a house built on [Marlowe's] foundations" (qtd. in Menon 2008, 111), will become the epitome of the com- 
mercially viable, exchange-based literary system as it emancipates itself from courtly patronage. Madden's film thus creates a fanciful version of an early seventeenth-century 'war of the theatres' which strongly resembles the emulative warrior-aristocrat behavioural structures dramatized in Troilus and Cressida.

It is perhaps appropriate that the star playwright Tom Stoppard was instrumental in writing the screenplay, given his own history of ('emulative'?) Shakespeare reworkings for the postmodern stage, Rosencrantz and Guildenstern are Dead (1968) and Dogg's Hamlet, Cahoot's Macbeth (1979). Shakespeare in Love stages a nostalgic commemoration of the concrete but limited time and place of theatrical performance from which film in turn would emancipate itself. It thus memorializes an earlier stage of transition: the film replicates in its own agonistic structure a prior interstitial moment in the gradual shift from a feudal system of masculine competition, often resulting in violence, and reposing upon the triangular exchange of women, to a commercial system of competition which eschewed extremes of 'emulative' violence because social stasis hindered the frictionless pursuit of profit. Just as the film self-reflexively mediates upon the theatrical predecessors of the celluloid, video and digital media, so too the early modern theatre dramatized the contradictions of the residual feudal systems and concomitant patronage-based media which it was in the process of superseding.

Thus Shakespeare in Love is an 'emulative text': it "stands in awe" of its Shakespearean predecessors (Anderegg 2003, 56), but none the less seeks, as a "film about Shakespeare", to place itself "in the same league as his own literate, crowd-pleasing plays" (Brode 2000, 240). It playfully competes with the theatrical medium itself (with which it also cooperates, doing some effective advertizing for the recently opened New Globe Theatre in London [Anderegg 2003, 64, see also West 2003]), as well aspiring to equal the high-cultural domain of 'Shakespeare'. To that extent, it performs what Troilus and Cressida had done: namely, it appropriates the domain of aristocratic 'emulative' violence for the cinema, making it the motor of its plot, and the lynchpin of a new sort of 'emulation', one based on commercial entertainment. This contemporary avatar of the 'anxiety of influence', both between Will and Kit Marlowe, and Stoppard/ Madden and Shakespeare, would corroborate the recalibration of 'emulation' I have argued for above. If this is so, Ryan is right in suggesting that contemporary consumer capitalism is the descendant of early modern 'emulation': “Acquisitive individualism, the feverish compulsion to compete and consume that is eating up full-grown consumer societies today, is the spawn of hierarchy, not the deadly cancer that threatens to destroy it" (Ryan 2007, 178).

I conclude this article with this brief meditation upon Madden's Shakespeare in Love because, in its imaginative recreation of the great age of early 
modern theatre, in part because of its tendency to foreshorten the distance between past and present (Anderegg 2003, 69), it captures the essential dynamic I have sought to explore here: namely, the way Shakespeare's theatre explored the aporia of early modern structures of masculine competition, known generically as 'emulation'. Such competition concealed an underlying homosociality which reposed upon the exchange of women; its structures of hostile competition underpinned by social similarity also generated a temporal stalemate in resulting in spiralling processes of violence; these in turn were experienced more and more by an emergent merchant-capitalist society as a brake upon the development of an increasingly hegemonic economic system of wealth- rather than rank-based competition which foreshadows, albeit from a great distance, salient elements of our own late-capitalist moment.

\section{Works Cited}

Agnew, Jean-Christophe. 1986. Worlds Apart: The Market and the Theater in Anglo-American Thought, 1550-1750. Cambridge: Cambridge University Press.

Anderegg, Michael. 2003. “James Dean Meets the Pirate's Daughter: Passion and Parody in William Shakespeare's Romeo + Juliet and Shakespeare in Love". Shakespeare the Movie II: Popularizing the Plays on Film, TV, Video and DVD. Ed. Richard Burt and Lynda E. Boose. New York: Routledge. 56-71.

Angerer, Paul. 1965. "Die Bühnenmusik als raumschafendes Element”. Maske und Koturn 11: 314-323.

Augustine, Saint. 1610. Of the Citie of God. Trans. J. H. London.

Barber, C. L. 1957. The Idea of Honour in the English Drama 1591-1700. Göterborg: Elanders Boktryckeri Aktiebolag.

Barker-Benfield, Graham John. 1992. The Culture of Sensibility: Sex and Society in EighteenthCentury Britain. Chicago: University of Chicago Press.

Barthes, Roland. 1975. "En sortant du cinema". Communications 23: 104-107.

Bataille, Georges. 1991. The Accursed Share: An Essay on General Economy. Volume 1: Consumption. Trans. Robert Hurley. New York: Zone.

Brode, Douglas. 2000. Shakespeare in the Movies: From the Silent Era to Shakespeare in Love. Oxford: Oxford University Press.

Bruster, Douglas. 1992. Drama and the Market in the Age of Shakespeare. Cambridge: Cambridge University Press.

Chambers, E. K. 1923. The Elizabethan Stage. 4 vols. Cambridge: Cambridge University Press.

Charnes, Linda. 1989. “'So Unsecret to Ourselves': Notorious Identity and the Material Subject in Shakespeare's Troilus and Cressida". Shakespeare Quarterly 40.4: 413-440.

Clarke, G. N. 1947. The Seventeenth Century. 2nd ed. Oxford: Oxford University Press.

Cole, Douglas. 1980. "Myth and Anti-Myth: The Case of Troilus and Cressida". Shakespeare Quarterly 31.1: 76-84. 
Dekker, Thomas. 1953-1962. The Dramatic Works of Thomas Dekker. Ed. Fredson Bowers. 4 vols. Cambridge: Cambridge University Press.

Dietrich, Margret. 1965. "Der Mensch und der szenische Raum”. Maske und Koturn 11: 193-206. Elam, Keir. 1980. The Semiotics of Theatre and Drama. London: Methuen.

Elton, William R. 2000. Shakespeare's Troilus and Cressida and the Inns of Court Revels. Aldershot: Ashgate.

Fernie, Ewan. 2007. “Action! Henry V”. Presentist Shakespeares. Ed. Hugh Grady and Terence Hawkes. London: Routledge: 97-120.

Fisher, F. J. 1948. "The Development of London as a Centre of Conspicuous Consumption in the Sixteenth and Seventeenth Centuries". Transactions of the Royal Historical Society 30: $37-50$.

Fly, Richard. 1975. "Cassandra and the Language of Prophecy in Troilus and Cressida". Shakespeare Quarterly 26: 157-171

Foakes, R. A. 2003. Shakespeare and Violence. Cambridge: Cambridge University Press.

Foakes, R. A., ed. 2002. Henslowe's Diary. 2nd ed. Cambridge University Press.

Foakes, R. A., ed. 2006. William Shakespeare: Troilus and Cressida. Harmondsworth: Penguin.

Foucault, Michel. 1966. Les Mots et les choses: Une Archéologie des sciences humaines. Paris: Gallimard.

Foucault, Michel. 2002. The Order of Things: An Archaeology of the Human Sciences. Trans. A. M. Sheridan Smith. London: Routledge.

Gil, Daniel Juan. 2001. "At the Limits of the Social World: Fear and Pride in Troilus and Cressida". Shakespeare Quarterly 52.3: 336-359.

Girard, René. 1985. "The Politics of Desire in Troilus and Cressida". Shakespeare and the Question of Theory. Ed. Patricia Parker and Geoffrey Hartman. New York: Methuen: 187-209.

Greenfield, Matthew A. 2000. "Fragments of Nationalism in Troilus and Cressida". Shakespeare Quarterly 51.2: 181-200.

Heinemann, Margot. 1980. Puritanism and Theatre: Thomas Middleton and Opposition Drama under the Early Stuarts. Cambridge: Cambridge University Press.

Hillman, David. 1997. "The Gastric Epic: Troilus and Cressida". Shakespeare Quarterly 48.3: 295-313.

Irigaray, Luce. 1985. This Sex Which Is Not One. Trans. Catherine Porter. Ithaca: Cornell University Press.

Jardine, Lisa. 1996. Worldly Goods: A New History of the Renaissance. London: Macmillan

Johnston, Andrew J. 2008. Performing the Middle Ages from Beowulf to Othello. Turnhout: Brepols.

Jonson, Ben. 1925-1961. Ben Jonson. Ed. C.H. Herford, Percy Simpson and Evelyn Simpson. 11 vols. Oxford: Clarendon Press.

Kiernan, Victor G. 1988. The Duel in European History: Honour and the Reign of Aristocracy. Oxford: Oxford University Press.

King, Thomas A. 1999. "Displacing Masculinity: Edward Kynaston and the Politics of Effeminacy". Images of Manhood in Early Modern Literature: Viewing the Male. Ed. Andrew P. Williams. Westport: Greenwood Press: 119-140.

Levinson, Stephen. 1983. Pragmatics. Cambridge: Cambridge University Press.

Lévi-Strauss, Claude. 1968. Structural Anthropology. Trans. Claire Jacobson and Brooke Grundfest Schoepf. Harmondsworth: Penguin. 
Lotman, Yuri. 1977. The Structure of the Artistic Text. Trans. Gail Lenhoff and Ronald Vroon. Ann Arbor: University of Michigan/Department of Slavic Languages and Literatures.

Mallin, Eric S. 1990. "Emulous Factions and the Collapse of Chivalry: Troilus and Cressida". Representations 29: 145-179.

Man, David. 1991. The Elizabethan Player: Contemporary Stage Representations. London: Routledge.

Martin, Priscilla, ed. 1976. Shakespeare Troilus and Cressida: A Casebook. London: Macmillan.

Menon, Madhavi. 2008. Unhistorical Shakespeare: Queer Theory in Shakespearean Literature and Film. New York: Palgrave Macmillan.

Muir, Kenneth, ed. 1956. Elizabethan and Jacobean Prose 1550-1620. Harmondsworth: Penguin.

Muir, Kenneth. 1982. "Introduction”. Shakespeare: Troilus and Cressida. Ed. Kenneth Muir. Oxford: Clarendon Press: 1-40.

Norman, Marc and Tom Stoppard. 1999. Shakespeare in Love: Screenplay. London: Faber.

Pietzcker, Carl. 2001. "On the Motif of the Man, Who, Although He Loves, Goes to War: On the History of the Construction of Masculinity in the European Tradition". Conceptions of Postwar German Masculinity. Ed. Roy Jerome. Albany: State University of New York Press: $134-170$.

Pfister, Manfred. 1988. Theory and Analysis of Drama. Trans. John Halliday. Cambridge: Cambridge University Press.

Roper, Lyndal. 1994. Oedipus and the Devil: Witchcraft, Sexuality and Religion in Early Modern Europe. London: Routledge.

Ryan, Kiernan. 2007. "Troilus and Cressida: The Perils of Presentism”. Presentist Shakespeares. Ed. Hugh Grady and Terence Hawkes. London: Routledge: 164-183.

Sedgwick, Eve Kosovsky. 1985. Between Men: English Literature and Male Homosocial Desire. New York: Columbia University Press.

Shakespeare in Love. 1998. Dir. John Madden. Perf. Gwyneth Paltrow, Joseph Fiennes and Geoffrey Rush. Miramax Films.

Shakespeare, William. 1988. The Complete Works: Compact Edition. Ed. Stanley Wells and Gary Taylor. Oxford: Clarendon Press/Oxford University Press.

Sharpe, J. A. 1987. Early Modern England: A Social History 1550-1760. London: Arnold.

Smith, Bruce R. 1999. The Acoustic World of Early Modern England. Chicago: University of Chicago Press.

de Somogyi, Nick. 1998. Shakespeare's Theatre of War. Aldershot: Ashgate.

Spear, Gary. 1993. "Shakespeare's 'Manly' Parts: Masculinity and Effeminacy in Troilus and Cressida". Shakespeare Quarterly 44.4: 409-422.

Stein, Arnold. 1969. "Troilus and Cressida: The Disjunctive Imagination”. English Literary History 36.1: 145-167.

Styan, John L. 1996. The English Stage: A History of Drama and Performance. Cambridge: Cambridge University Press/Canto.

Thomas, Keith. 2009. The Ends of Life: Roads to Fulfilment in Early Modern England. Oxford: Oxford University Press.

Tiffany, Grace. 1993. "Not Saying No: Female Self-Erasure in Troilus and Cressida". Texas Studies in Literature and Language 35.1: 44-56

Todorov, Tzvetan. 1969. Gramaire du Décaméron. The Hague: Mouton.

Turner, Henry S. 2006. The English Renaissance Stage: Geometry, Poetics, and the Practical Spatial Arts 1580-1630. Oxford: Oxford University Press. 
Turner, James. 1979. The Politics of Landscape: Rural Scenery and Society in English Poetry 1630-1660. Oxford: Blackwell.

Underdown, David. 1993. Fire From Heaven: Life in an English Town in the Seventeenth Century. London: Fontana/HarperCollins.

Wells, Robin H. 2000. Shakespeare on Masculinity. Cambridge: Cambridge University Press.

West, Russell. 2002. Spatial Representation and the Jacobean Stage: From Shakespeare to Webster. Basingstoke: Palgrave Macmillan.

West, Russell. 2003. “Cultural Catachresis and Cultural Memory at London's New Globe Theatre". Journal for the Study of British Cultures 10.2: 201-216.

Willson, David Harris. 1966. King James VI \& I. London: Jonathon Cape.

Wilson, John Dover, ed. 1959. Life in Shakespeare's England. Harmondsworth: Pelican. 
Copyright of Anglia-Zeitschrift für englische Philologie is the property of De Gruyter and its content may not be copied or emailed to multiple sites or posted to a listserv without the copyright holder's express written permission. However, users may print, download, or email articles for individual use. 